\title{
Coral calcification from skeletal records revisited
}

\author{
Janice M. Lough* \\ Australian Institute of Marine Science, PMB 3, Townsville MC, Queensland 4810, Australia
}

\begin{abstract}
Skeletal growth records in annually banded massive coral skeletons are an underexploited archive of coral responses to environmental changes. Average linear extension and calcification rates in Indo-Pacific Porites are linearly related to average water temperatures through 23 to $30^{\circ} \mathrm{C}$. Assessing long-term trends in Porites extension and density requires caution as there is evidence of an age effect whereby in earlier growth years corals will tend to extend less and form a higher density skeleton than in later years. This does not appear to affect calcification rates. Coral growth characteristics at 2 of 3 reefs in the central Great Barrier Reef provide evidence of a recent decline. This is of concern, although the exact causes cannot be identified. International efforts are required to make full use of both coral growth histories and geochemical tracers contained in massive coral skeletons to understand the nature and significance of recent trends and their possible links with environmental changes such as ocean chemistry, warming tropical oceans and increased frequency of coral bleaching events.
\end{abstract}

KEY WORDS: Coral calcification · Porites $\cdot$ Temperature $\cdot$ Climate $\cdot$ Great Barrier Reef

\section{INTRODUCTION}

The discovery of alternating dense and less dense bands in the calcium carbonate $\left(\mathrm{CaCO}_{3}\right)$ skeletons of massive corals and their confirmation as annual by autoradiography (Knutson et al. 1972) and radiometric techniques (Macintyre \& Smith 1974, Moore \& Krishnaswami 1974) opened the door to the 'vast storehouses of information about chemical and physical changes of waters in which they grew' (Moore \& Krishnaswami 1974, p. 274). These annual density bands are apparent when slices of coral skeleton, taken perpendicular to the main vertical growth axis of the colony, are X-rayed. Knowing the date of collection of the sample, well-displayed annual band pairs, consisting of a dense and less dense band per year, can be counted back through time to provide a chronology of coral growth.

Starting from this basis, 2 main types of dated records have been obtained from massive corals. The first is growth data, i.e. annual linear extension rate, average annual skeletal density and, combining these, the mass of $\mathrm{CaCO}_{3}$ deposited per year (calcification rate). Hiatuses in coral growth and unusual banding patterns, such as 'stress' bands, can also be seen on X-rays of coral slices. The second derives from geochemical composition analyses of the calcium carbonate skeleton: a wealth of isotopic and geochemical tracers are incorporated into the skeleton during growth (known as 'inclusive' records) and are measured in samples removed from along major growth axes of the coral.

In the $36 \mathrm{yr}$ since the discovery of annual density bands, nearly 800 papers have been published describing analyses of records obtained from massive coral skeletons. In the first $15 \mathrm{yr}$ after their discovery, the majority $(60 \%)$ of papers examined the annual bands as records of coral growth. In the most recent $15 \mathrm{yr}$ period, however, the vast majority of papers $(80 \%)$ have dealt with analyses of inclusive records. This change in focus is also reflected in recent reviews by the almost exclusive emphasis on proxy climate and environmental records provided by geochemical tracers from corals (Gagan et al. 2000, Cole 2003, Felis \& Patzold 2003, Correge 2006, Grottoli \& Eakin 2007). The annual density banding 
pattern appears to have been relegated to the role of an initial visualisation tool for identifying transects for subsequent geochemical analyses and to assist in establishing a chronology. Does this change in focus mean that coral growth records now provide little useful information?

There is now a variety of experimental, modelling and theoretical evidence that coral calcification rates (and those of other marine calcifying organisms) will decrease as the oceans continue to absorb part of the excess atmospheric $\mathrm{CO}_{2}$ produced by anthropogenic activities (Royal Society 2005, Kleypas et al. 2006). In this article, I consider how annual growth records from massive coral skeletons, the commonly used IndoPacific Porites spp., can contribute to identifying the possible consequences of increasing ocean acidification and warming water temperatures for a major marine calcifying organism. I present

- An update on the spatial temperature control of average Porites growth characteristics

- Evidence for possible age effects on coral growth records that could confound detecting long-term trends

- Evidence for recent coral growth changes from 3 reefs in the central Great Barrier Reef (GBR), Australia.

\section{MEASURING CORAL GROWTH VARIABLES}

Three variables describing coral growth can be obtained from the annual density banding pattern: (1) how much the coral is extending each year-i.e. the linear extension rate measured between annual density minima or maxima $\left(\mathrm{mm} \mathrm{yr}^{-1}\right)$; (2) average annual skeletal density $\left(\mathrm{g} \mathrm{cm}^{-3}\right)$; and (3) the calcification rate ( $\mathrm{g} \mathrm{cm}^{-2} \mathrm{yr}^{-1}$ ) -i.e. the multiple of the first 2 variables, which provides the mass of $\mathrm{CaCO}_{3}$ skeleton deposited per year. These are typically obtained from skeletal slices ( $7 \mathrm{~mm}$ thick) cut along the plane of the vertical growth axis of a coral core or colony.
The most commonly reported coral growth variable is the linear extension rate. This can be measured directly from X-ray positive prints of skeletal slices with the annual bandwidth defined as the linear distance between equivalent parts of adjacent annual density band pairs (e.g. Hudson 1981). A variety of techniques have been used to measure the less commonly reported skeletal density variable. These include the destructive technique of removing sections of skeleton and determining the weight and volume, and hence the density (e.g. Highsmith 1979, CarricartGanivet et al. 2000) and the following non-destructive techniques: 'photo' or 'optical' scanning of the coral X-ray with appropriate $\mathrm{CaCO}_{3}$ standards to obtain absolute skeletal density (e.g. Aller \& Dodge 1974, Buddemeier et al. 1974, Grigg 1981, Helmle et al. 2002); computerized tomography (CT) scanning of a coral slice (Logan \& Anderson 1991, Bessat \& Buigues 2001); and gamma densitometry (Fig. 1), which measures the attenuation through the thickness of a coral slice of a beam of gamma photons (e.g. Chalker \& Barnes 1990, Draschba et al. 2000) and has been shown to produce comparable measurements to the optical technique (Carricart-Ganivet \& Barnes 2007). Once measurements of linear extension and skeletal density have been obtained, it is simple to produce annual calcification rates.

Unless indicated otherwise, all material used in the following analyses were from the Australian Institute of Marine Science collection of small coral colonies and coral cores (see Lough et al. 1999) and some recently collected short $(\sim 50 \mathrm{~cm}$ length) cores from Porites corals growing in shallow-water $(<10 \mathrm{~m})$ environments of the Great Barrier Reef (GBR), Australia. Dated skeletal growth variables were obtained by gamma densitometry of the coral slices (Lough \& Barnes 1997, 2000). For comparative analyses of growth records from different corals, each dated coral series was first standardized by dividing by the long-term mean of

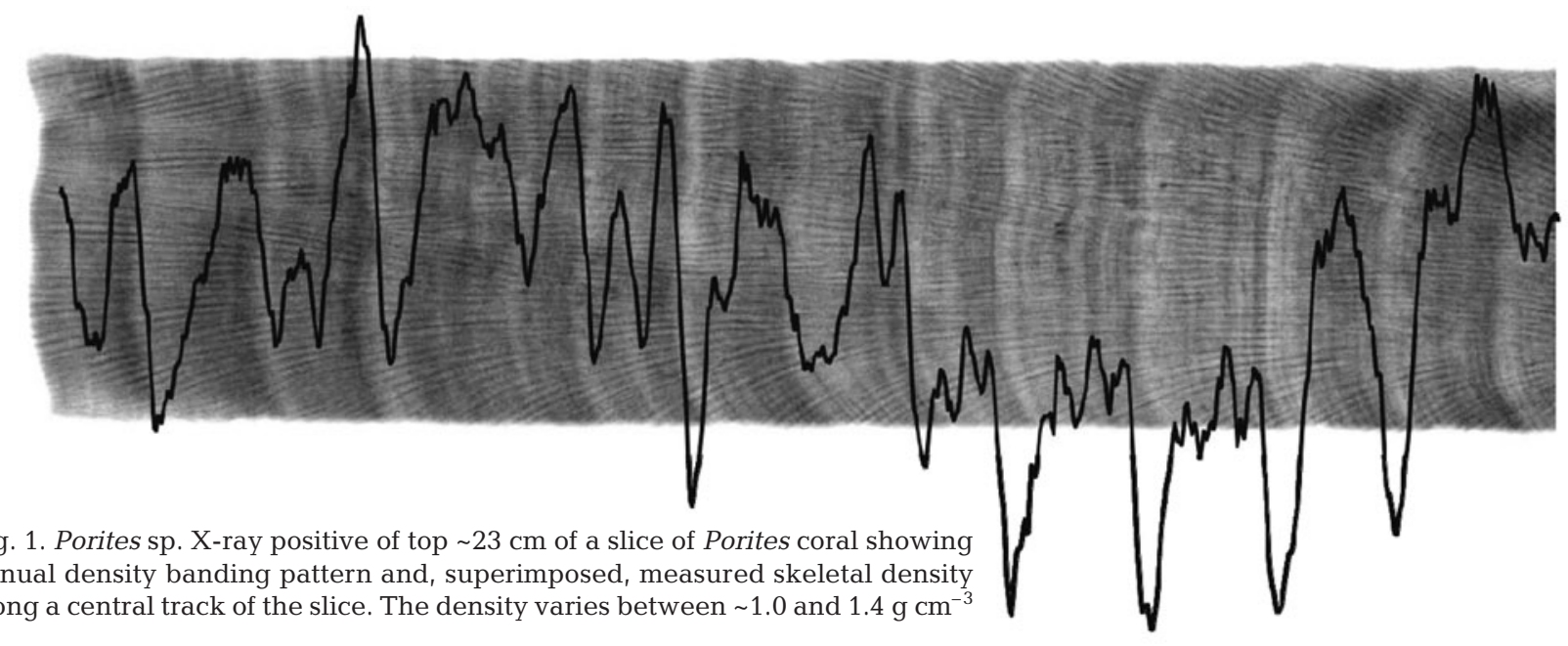
annual density banding pattern and, superimposed, measured skeletal density
along a central track of the slice. The density varies between $\sim 1.0$ and $1.4 \mathrm{~g} \mathrm{~cm}^{-3}$ 
each series. This allowed comparisons of relative trends amongst corals with differing average skeletal growth parameters. Standard linear regression techniques were used to examine relationships between variables and through time.

\section{TEMPERATURE CONTROL ON AVERAGE PORITES GROWTH CHARACTERISTICS}

Average coral growth rates in Porites from 44 IndoPacific reefs were analysed by Lough \& Barnes (2000). This dataset has been expanded to 49 reefs with the addition of growth data for 15 short Porites cores from 4 sites in the Arabian Gulf $\left(\sim 28^{\circ} \mathrm{N}, 50^{\circ} \mathrm{E}\right)$ (Poulsen et al. 2006) and 11 Porites colonies from Lihir Island, Papua New Guinea $\left(\sim 3^{\circ} \mathrm{S}, 153^{\circ} \mathrm{E}\right)$ (J. M. Lough unpubl. data). For the 49 sites, as reported previously (Lough \& Barnes 2000), average skeletal density was inversely related to linear extension rate and calcification rate $\left(\mathrm{r}^{2}=0.57, \mathrm{p}<0.000 ; \mathrm{r}^{2}=0.35, \mathrm{p}<0.000\right.$, respectively) and linear extension is the main source of variability in calcification rate $\left(\mathrm{r}^{2}=0.94, \mathrm{p}<0.000\right)$.

Even with the addition of new data for 5 sites (including Lihir Island with the warmest, of all the 49 sites, average annual sea surface temperature [SST] of $29.5^{\circ} \mathrm{C}$ ) there is no change in the significant linear relationship between average annual SST and Porites growth characteristics found by Lough \& Barnes (2000); average linear extension increases $\sim 3 \mathrm{~mm} \mathrm{yr}^{-1}$ and average calcification by $\sim 0.33 \mathrm{~g} \mathrm{~cm}^{-2} \mathrm{yr}^{-1}$ for each $1^{\circ} \mathrm{C}$ rise in average SSTs (Fig. 2).

Average linear extension and calcification rates in the massive coral Porites are significantly linearly related to average SST. This spatially derived relationship is evident based on corals growing in average water temperatures between $\sim 23$ to $30^{\circ} \mathrm{C}$. Earlier evidence of increasing coral extension and calcification rates obtained from long coral cores (covering the past 200 to $250 \mathrm{yr}$ ) that matched observed temperature increased suggested that, at least initially, some corals may respond to global warming by increasing their growth rates (Lough \& Barnes 2000, Bessat \& Buigues 2001). This neglects 3 other possible responses of coral growth to the enhanced greenhouse effect. The first of these is reduced or impaired growth as a result of more frequent mass coral bleaching events, though massive Porites tend to be more thermally tolerant than branching species (Marshall \& Baird 2000). Several recent Porites coral cores from the Great Barrier Reef did, however, show growth hiatuses associated with the 1998 and 2002 (Berkelmans et al. 2004) mass coral bleaching events on the GBR (J. M. Lough pers. obs.). The second response is the reduced coral growth as a result of changing ocean chemistry reducing the abil-
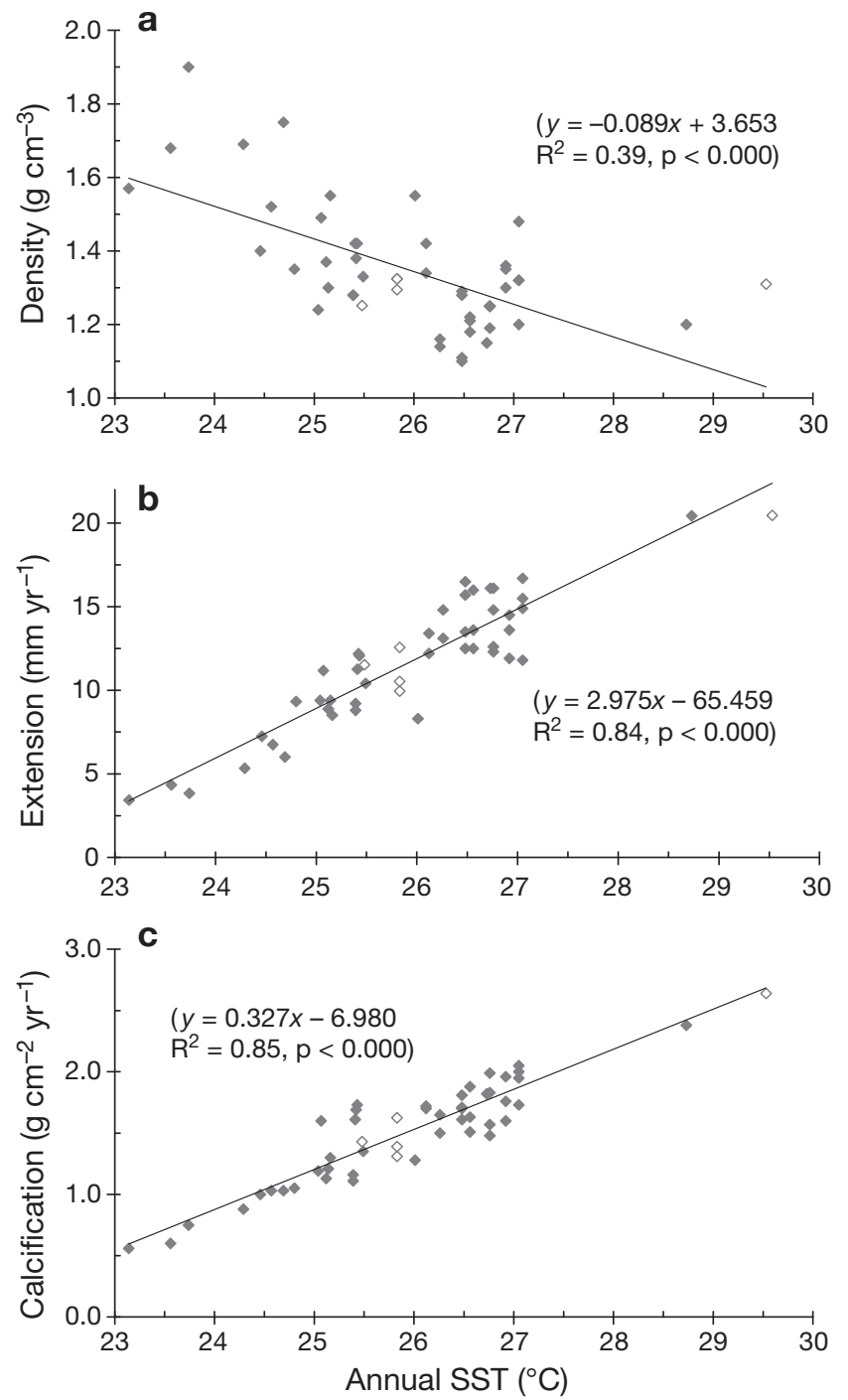

Fig. 2. Porites spp. Porites growth data averaged across colonies from each of 49 reefs vs. annual average sea surface temperature (SST) for (a) density, (b) extension and (c) calcification. Linear regressions also shown. Open diamonds are data for 4 sites in the Arabian Gulf and 1 site at Lihir Island

ity of marine calcifying organisms to form their skeletons (Kleypas et al. 1999), and the third possibility is a non-linear response of coral calcification rates to rising water temperatures with calcification reaching a plateau and then declining at higher temperatures (Jokiel \& Coles 1977, Marshall \& Clode 2004, Kleypas et al. 2005, Cooper et al. 2008).

\section{AGE EFFECTS ON CORAL GROWTH RECORDS}

Tree-ring widths typically exhibit an age effect with the young tree producing wider annual rings which progressively decrease in width as the tree ages (Fritts 1976). This 'growth curve' artefact has to be removed 
before using tree-ring width chronologies for dendroclimatic reconstructions. There has, to date, been no systematic analyses of possible age effects on growth records from massive corals, though Lough \& Barnes (1997) noted 'a tendency for higher density to be associated with lower extension rates during the early parts' of 35 long cores from the GBR.

To test for possible age effects on coral growth parameters, growth variables were taken from 43 long Porites cores with at least $100 \mathrm{yr}$ of record. The earliest start year was 1572 and the latest 1900. The cores were from inshore, mid-shelf and offshore reefs between $\sim 10^{\circ}$ to $24^{\circ} \mathrm{S}$ on the GBR. All 43 series were then set to start in Year 1, regardless of the actual start year of the record. This start year was the earliest dated year in each core, which was not necessarily the first year of growth of the coral. The 43 series were then averaged for successive 10 and $20 \mathrm{yr}$ periods and tested for significant linear trends with age.

Analysis of age effects in these 43 long-core records all scaled to start in the same year confirms the earlier observation of Lough \& Barnes (1997) (Fig. 3). Extension rate showed a significant increase through time though modulated by multidecadal variability. Skeletal density showed a more marked and significant decrease in, at least, the first $100 \mathrm{yr}$ of growth. Average extension rate in Years 61 to 80 and 81 to 100 were significantly higher than in the first $20 \mathrm{yr}$ of record. Average skeletal density in all 20 yr periods up to Years 81 to 100 were significantly lower than in the first $20 \mathrm{yr}$ of record. There was, however, no significant trend in calcification rate associated with colony age.

Application of skeletal growth records to the detection of changes associated with environmental trends, such as decreasing aragonite saturation state and warming water temperatures, requires that the coral's growth characteristics do not change with colony age. Evidence presented here shows that there is an age effect on skeletal density and, to a lesser extent, on linear extension rate in long-lived Porites, but not on calcification rate. This is important as it indicates: (1) longterm trends in coral calcification are not biased by age effects, (2) a trend of decreasing skeletal density on its own could potentially be associated with an age effect, but (3) a trend of decreasing density and decreasing extension are unlikely to be associated with an age effect.

\section{RECENT CORAL GROWTH CHANGES IN THE CENTRAL GBR}

To examine recent changes in coral growth characteristics, coral growth records were examined from 3 reefs in the central section of the GBR: Pandora Reef, an inshore reef (based on between 9 to 25 coral
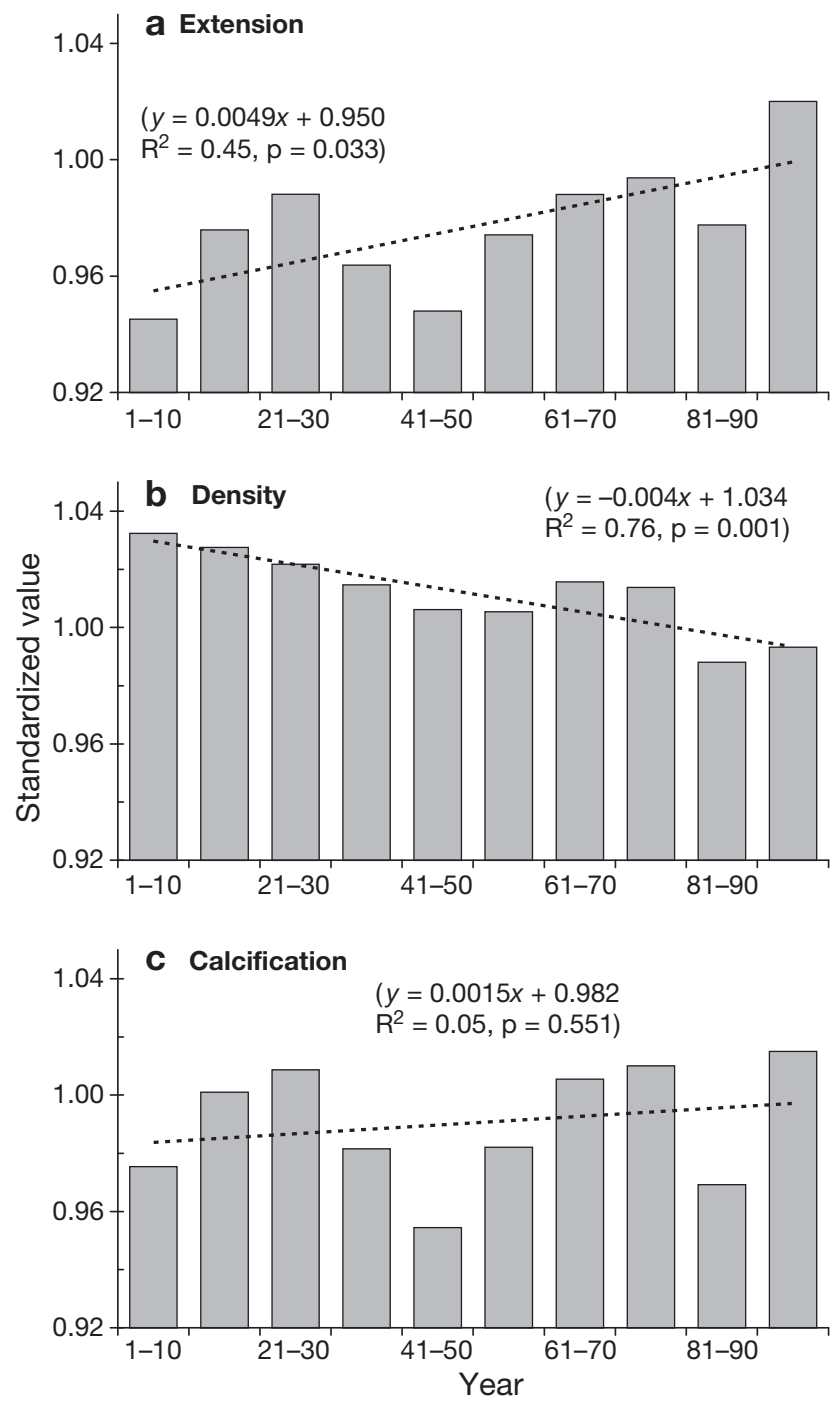

Fig. 3. Porites spp. Standardized growth variables for 43 coral cores averaged for $10 \mathrm{yr}$ periods for (a) extension, (b) density and (c) calcification with all cores starting from Year 1 regardless of actual age. Linear regressions also shown

records); Rib Reef, a mid-shelf reef (8 to 27 records); and Myrmidon Reef, an offshore reef (12 to 25 records). Standardized series of linear extension, skeletal density and calcification were averaged for $5 \mathrm{yr}$ periods from 1961 to 1965 through 2001 to 2005 and compared to similarly averaged SST data (Rayner et al. 2003).

For Pandora Reef (Fig. $4 a-c)$ there was a significant decrease through time in linear extension and calcification but no significant trend in skeletal density. There were no significant trends in any of the 3 growth variables at Rib Reef, although linear extension and calcification were notably lower in the most recent $5 \mathrm{yr}$ period (Fig. 4d-f). At Myrmidon Reef, there was a significant decrease through time in skeletal density and calcification rate and although extension also de- 

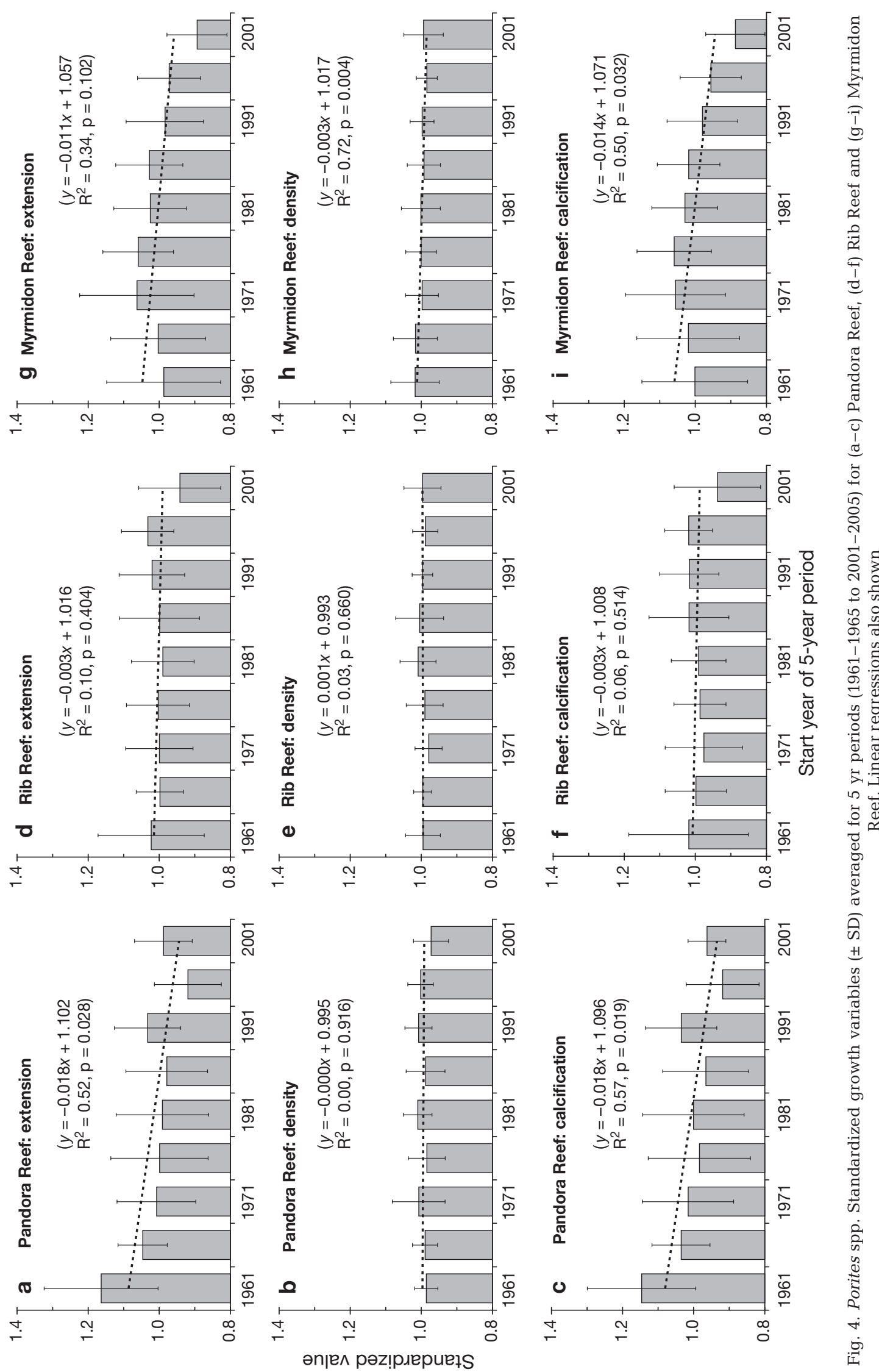
creased, the trend was not significant (Fig. 4g-i). Although there was a certain amount of variability in the $5 \mathrm{yr}$ averages (indicated by the overlapping error bars in Fig. 4) there was evidence of significant decline in calcification rates over the most recent $45 \mathrm{yr}$ period at an inshore (Pandora) and an offshore (Myrmidon) reef in the central GBR. Average annual SSTs on the GBR have significantly warmed since the late 19th century (Lough 2007) and, based on analysis of proxy SST records obtained from massive coral skeletons (Hendy et al. 2002) updated to the present (Lough et al. 2006), are probably the warmest in, at least, the past $\sim 250$ yr. In the central GBR there has been significant warming over the $45 \mathrm{yr}$ period corresponding to the examined coral growth records (Fig. 5). Applying the equations linking average annual SST and skeletal extension and calcification rates (Fig. 1) to the observed change in SST between 1961 to 1965 and 2001 to 2005, would give, if only SST was driving coral growth, an increase in extension and calcification rates $\sim 12$ to $13 \%$. The observed changes are, however, decreases in linear extension and calcification by $\sim 15$ to $16 \%$ at Pandora Reef and by 9 to $11 \%$ at Myrmidon Reef.

Evidence of enhanced calcification rates in long Porites cores from the GBR (Lough \& Barnes 2000) only provided data from 1780 through 1979. Results presented here for an inshore (Pandora) and an offshore (Myrmidon) reef in the central GBR, and recently published analyses for 2 nearshore regions in the northern GBR (Cooper et al. 2008), that include growth data subsequent to 1979 show, however, a recent decline in coral growth characteristics. An apparent recent decline in Porites growth in the Arabian Gulf was also noted by Lough et al. (2003). In all of these studies, there has been significant warming of ocean temperatures that may have been expected to enhance growth. The exact causes of these declines cannot be identified

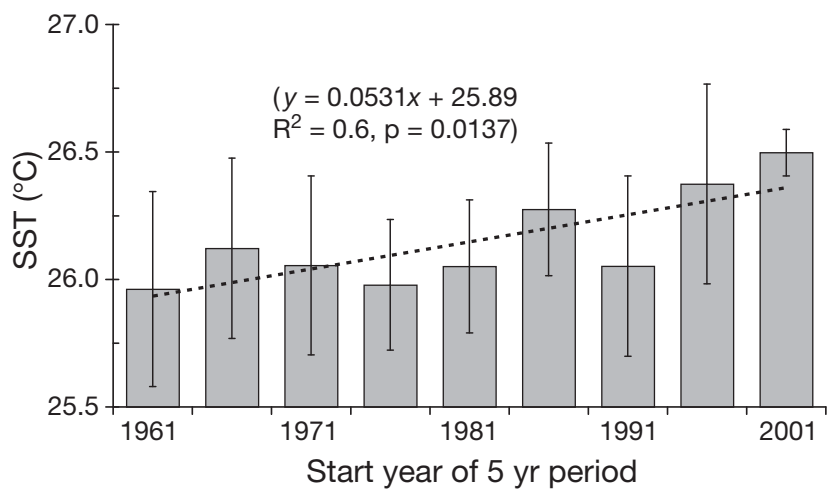

Fig. 5. Average 5 yr (1961-1965 to 2001-2005) sea surface temperature (SST) $( \pm \mathrm{SD})$ at $18.5^{\circ} \mathrm{S}, 146.5-147.5^{\circ} \mathrm{E}$. Data from HadlSST (Rayner et al. 2003). Linear regression also shown at present (see Cooper et al. 2008) nor can they, at present, be directly related to lower aragonite saturation state. They may also be evidence of a thermal control on coral calcification rates that have reached an optimum and have now started to decline. There is, however, now some disturbing field evidence, from this study and Cooper et al. (2008) for recent declining growth in massive Porites.

\section{CONCLUSIONS}

The skeletal growth histories contained in massive coral skeletons can make a significant contribution to assessing coral responses to environmental changes. This is particularly important in an era of rapidly changing global climate, warming oceans, and changing global ocean chemistry, in addition to local stresses to coral reefs. Massive coral skeletons containing annual density bands provide dated coral growth histories that can be exploited to assess the consequences of environmental changes (as originally envisaged by Knutson et al. 1972), including progressive ocean acidification. These sources of coral growth histories can be used to determine base-line growth rates and natural variability prior to anthropogenic changes to coral reef environments and global warming, and help detect current changes. Routine examination of coral growth characteristics in conjunction with geochemical analyses of the same material can greatly enhance the environmental information obtained from coral archives. These retrospective monitors of coral reef environments are at present underexploited. There are, for example, a large number of coral cores collected in recent years primarily for the analyses of geochemical records and reconstruction of past oceanic climates and environments (www.ncdc.noaa.gov/paleo/index. html). Rarely are details of coral growth provided, yet, at the very least, annual linear extension rates can be readily measured from X-rays of coral slices or determined from high-resolution sampled geochemical records with annual cycles (similar to obtaining extension rates from skeletal density). There are also several collections of massive coral colonies, some of which have been analysed in terms of coral growth characteristics (e.g. Hudson 1981, Lough et al. 1999, CarricartGanivet \& Merino 2001, Dodge \& Helmle 2003, Halley \& Hudson 2007). There is an urgent need to ensure that this valuable material is not lost and that the information on coral growth rates is obtained from these under-used archives. This requires a coordinated international effort to both identify what material is available, to ensure it is appropriately curated and encourage the routine measurement of coral skeletal growth records in concert with geochemical analyses. 
Acknowledgements. Thanks to Ray Berkelmans, Eric Matson and Damian Thomson (AIMS) for collection of recent short Porites cores from the Great Barrier Reef and to Eric Matson for skilled technical support in sample preparation and analysis. The author also thanks 2 anonymous reviewers and the Editor for their very helpful comments.

\section{LITERATURE CITED}

Aller RC, Dodge RE (1974) Animal-sediment relations in a tropical lagoon Discovery Bay, Jamaica. J Mar Res 32: 209-232

Berkelmans R, De'ath G, Kininmonth S, Skirving WJ (2004) A comparison of the 1998 and 2002 coral bleaching events on the Great Barrier Reef: spatial correlation, patterns and predictions. Coral Reefs 23:74-83

Bessat F, Buigues D (2001) Two centuries of variation in coral growth in a massive Porites colony from Moorea (French Polynesia): a response of ocean-atmosphere variability from south central Pacific. Palaeogeogr Palaeoclimatol Palaeoecol 175:381-392

Buddemeier RW, Maragos JE, Knutson DW (1974) Radiographic studies of reef coral exoskeletons: rates and patterns of coral growth. J Exp Mar Biol Ecol 14:179-200

Carricart-Ganivet JP, Barnes DJ (2007) Densitometry from digitized images of X-radiographs: methodology for measurement of coral skeletal density. J Exp Mar Biol Ecol 344:67-72

Carricart-Ganivet JP, Merino M (2001) Growth responses of the reef-building coral Montastrea annularis along a gradient of continental influence in the southern Gulf of Mexico. Bull Mar Sci 68:133-146

Carricart-Ganivet JP, Beltrán-Torres AU, Merino M, RuizZárate MA (2000) Skeletal extension, density and calcification rate of the reef building coral Montastrea annularis (Ellis and Solander) in the Mexican Caribbean. Bull Mar Sci 66:215-224

Chalker BE, Barnes DJ (1990) Gamma densitometry for the measurement of skeletal density. Coral Reefs 9:11-23

Cole JE (2003) Holocene coral records: windows on tropical climate variability. In: Mackay A, Battarbee R, Birks J, Oldfield F (eds) Global change in the Holocene, Arnold, London, p 168-184

Cooper TF, De'ath G, Fabricius KE, Lough JM (2008) Declining coral calcification in massive Porites in 2 nearshore regions of the northern Great Barrier Reef. Glob Change Biol 2008 14:529-538

Correge T (2006) Sea surface temperature and salinity reconstruction from coral geochemical tracers. Palaeogeogr Palaeoclimatol Palaeoecol 232:408-428

Dodge RE, Helmle KP (2003) Past stony coral growth (extension) rates on reefs of Broward County, Florida: possible relationships with Everglades's drainage. Presented Poster, Joint Conf on Science and Restoration of the Greater Everglades and Florida Bay Ecosystem. Palm Harbor, Florida. April 13-18. Available at: www.nova.edu/ocean/ncri/ projects/geer/index.html

Draschba S, Patzold J, Wefer G (2000) North Atlantic climate variability since AD 1350 recorded in $\delta^{18} \mathrm{O}$ and skeletal density of Bermuda corals. Int J Earth Sci 88:733-741

Felis T, Patzold J (2003) Climate records from corals. In: Wefer G, Lamy F, Mantoura F (eds) Marine science frontiers for Europe. Springer-Verlag, Berlin, p 11-27

Fritts HC (1976) Tree rings and climate. Academic Press, London

Gagan MK, Ayliffe LK, Beck JW, Cole JE, Druffel ERM,
Dunbar RB, Schrag DP (2000) New views of tropical paleoclimates from corals. Quat Sci Rev 19:45-64

Grigg RW (1981) Coral reef development at high latitude in Hawaii. In: Proc 4th Int Coral Reef Symp, Manila, 1: 687-693

> Grottoli AG, Eakin CM (2007) A review of modern coral $\delta^{18} \mathrm{O}$ and $\Delta^{14} \mathrm{C}$ proxy records. Earth Sci Rev 81:67-91

Halley RB, Hudson JH (2007) Fidelity of annual growth in Montastraea faveolata and the recentness of coral bleaching in Florida. In: Aronson RB (ed) Geological approaches to coral reef ecology. Springer, Berlin, p 161-177

Helmle KP, Dodge RE, Ketcham RA (2002) Skeletal architecture and density banding in Diploria strigosa by X-ray computed tomography. In: Proc 9th Int Coral Reef Symp, Bali, Indonesia 23-27 October 2000, 1:365-371

> Hendy EJ, Gagan MK, Alibert CA, McCulloch MT, Lough JM, Isdale PJ (2002) Abrupt decrease in tropical Pacific sea surface salinity marks end of Little Ice Age. Science 295:1511-1514

> Highsmith RC (1979) Coral growth rates and environmental control of density banding. J Exp Mar Biol Ecol 37: $105-125$

Hudson JH (1981) Growth rates in Montastrea annularis: a record of environmental change in Key Largo Reef Marine Sanctuary, Florida. Bull Mar Sci 31:444-459

Jokiel PL, Coles SL (1977) Effects of temperature on the mortality and growth of Hawaiian reef corals. Mar Biol 43: 201-208

> Kleypas JA, Buddemeier RW, Archer D, Gattuso JP, Langdon C, Opdyke BN (1999) Geochemical consequences of increased atmospheric $\mathrm{CO}_{2}$ on coral reefs. Science 284:118-120

Kleypas JA, Buddemeier RW, Eakin CM, Gattuso JP and others (2005) Comment on 'Coral reef calcification and climate change: the effect of ocean warming'. Geophys Res Lett 32:L08601, doi:10.1029/2004GL022329

Kleypas JA, Feely RA, Fabry VJ, Langdon C, Sabine CL, Robbins LL (2006) Impacts of ocean acidification on coral reefs and other marine calcifiers: a guide for future research. Report of a workshop held 18-20 April 2005, St Petersburg, FL, sponsored by NSF, NOAA and the US Geological Survey

Knutson DW, Buddemeier RW, Smith SV (1972) Coral chronometers: seasonal growth bands in reef corals. Science 177: $270-272$

Logan A, Anderson IH (1991) Skeletal extension growth rate assessment in corals, using CT scan imagery. Bull Mar Sci 49:847-850

Lough JM (2007) Climate and climate change on the Great Barrier Reef. In: Johnson JE, Marshall PA (eds). Climate change and the Great Barrier Reef. Great Barrier Reef Marine Park Authority and Australian Greenhouse Office, Australia, p 15-50

Lough JM, Barnes DJ (1997) Several centuries of variation in skeletal extension, density and calcification in massive Porites colonies from the Great Barrier Reef: a proxy for seawater temperature and a background of variability against which to identify unnatural change. J Exp Mar Biol Ecol 211:29-67

Lough JM, Barnes DJ (2000) Environmental controls on growth of the massive coral Porites. J Exp Mar Biol Ecol 245:225-243

Lough JM, Barnes DJ, Devereux MJ, Tobin BJ, Tobin S (1999) Variability in growth characteristics of massive Porites on the Great Barrier Reef. CRC Reef Research Centre Technical Report No 28. CRC Reef Research Centre, Townsville

Lough JM, Devereux MJ, Barnes DJ (2003) Porites coral 
growth records from the Arabian Gulf. Australian Institute of Marine Science, Townsville

Lough J, Berkelmans R, van Oppen M, Wooldridge S, Steinberg C (2006) The Great Barrier Reef and climate change. Bull Aust Meteor Ocean Soc 19:53-58

Macintyre IG, Smith SV (1974) X-radiographic studies of skeletal development in coral colonies. In: Proc 2nd Int Coral Reef Symp 2:277-287

Marshall AT, Clode P (2004) Calcification rate and the effect of temperature in a zooxanthellate and an azooxanthellate scleractinian reef coral. Coral Reefs 23:218-224

Marshall PA, Baird AH (2000) Bleaching of corals on the Great Barrier Reef: differential susceptibilities among taxa. Coral Reefs 19:155-163

Submitted: September 5, 2007; Accepted: January 15, 2008
Moore WS, Krishnaswami S (1974) Correlation of X-radiography revealed banding in corals with radiometric growth rates. In: Proc 2nd Int Coral Reef Symp 2:269-276

Poulsen A, Burns K, Lough J, Brinkman D, Delean S (2006) Trace analysis of hydrocarbons in coral cores from Saudi Arabia. Org Geochem 37:1913-1930

Rayner NA, Parker DE, Horton EB, Folland CK and others (2003) Global analyses of sea surface temperature, sea ice and night marine air temperature since the late nineteenth century. J Geophys Res 108(D14), 4407, doi:10.1029/2002 JD002670

Royal Society (2005) Ocean acidification due to increasing atmospheric carbon dioxide. Policy document 12/05. The Royal Society, London

Proofs received from author(s): November 5, 2008 